\title{
Trade union activity, cultural, public and political life of Krasnoyarsk Polytechnic Institute in the second half of 1950s- 1980
}

\author{
Valeriy V. Petrik ${ }^{1, a}$, Tatiana B. Lysunets ${ }^{1}$, and Daria A. Cheremisinova ${ }^{1}$ \\ ${ }^{1}$ Tomsk polytechnic university, 634050 Lenina str., 30, Tomsk, Russia
}

\begin{abstract}
Basing on rich documentary, the article studies the activity of the trade union organization in Krasnoyarsk Polytechnic Institute and the impact the trade union had on the cultural, public and political life of the Institute in the second half of the 1950s-1980s. The activity is stated to be held in different forms and areas: amateur arts, propaganda, wall-newspaper and house magazine, vigilant groups, University of Culture, student club, lecturing agitation group, student construction brigades, department, groups and hostels competitions. The authors come to the conclusion that involving students and faculty members into cultural, public and political life added greatly to fostering the future engineers as it took them less time to adapt to the team-spirited workforce after graduating from the higher educational establishment. The article is intended for the people interested in history of higher education in Siberia and Russia.
\end{abstract}

\section{Introduction}

Higher technical education has always been on special note in the system of tertiary education in Russian Federation. Training engineers for leading brunches of home industry fosters strengthening of the economical independence of the country and promotes improvement of the live standards. The task can be successfully fulfilled on the basis of outrunning growth of engineering higher educational establishment network and providing the on going training process of highly qualified specialists.

Thus, there has been traced the raise of the interest to the history of high technical schools in the country as a whole and to the local history in particular, especially to the period from the second half of the 1950s -the 1980s. High technical schools of such a great industrial and cultural center as Krasnoyarsk are not an exception. At the period reviewed, in Krasnoyarsk there was opened a Polytechnic Institute. Studying the traditions of high schools of Soviet period contributes to deeper understanding of the modern processes in this sphere of education.

\section{Materials and methods}

The resource base of the article was formed on studying a wide range of unpublished materials and sources taken from the funds of Archival repository and research center of Recent History of Krasnoyarsk Territory

\footnotetext{
a Corresponding author: v.v.petrik@mail.ru
}

(ARRCRHKT): Collection 6727 (The Primary Party organization of Krasnoyarsk Polytechnic Institute).

An important source in historical studies of Krasnoyarsk Polytechnic Institute (KPI) in the second half of 1950s-1980s and studies of its human resources is the office work documentary: reports on work, staff reports and references on KPI, orders of rectors, reports on the work of trade union organizations and scientific activity of the institute, the minutes of meetings of the Academic Board, faculties and departments of KPI, syllabuses, correspondence between the administration of the institute and the Ministry of Higher and secondary vocational education of the Russian Soviet Federated Socialist Republic, academic and sectoral research institutes, industrial enterprises and power structures. The documents of the primary party organization are of special interest as they give the critical analysis of the deans office activities, the activities of the trade union committee and the academic staff of the university in different arias. They give the opportunity to follow the transformation of the structure of academic and scientific, and academic support divisions of KPI, to reveal the content and the character of the specialist training process, to characterize the trade union activity, cultural and political life of KPI in the given period.

There were used the principles of historism and objectivity that are the basic worldview guides for studying any of the questions raised. The problemchronological and narrative methods were taken as the basis for the work. 


\section{Results and discussion}

Trade union organization made a great impact on cultural, public and political life of Krasnoyarsk Polytechnic Institute (KPI) in the second half of the 1950s-1980s. From the outset, the improvement of housekeeping and living condition of the academic staff, faculty members and students was the main concern of the trade union which, at first, combined the academic staff and the students' trade unions. The trade union consisted of the most active members of the institute: A. Zubkov, T. Kuzmina, V. Volkov, G. Mikhailov.

First months of the work of the KPI trade union were devoted to the most essential needs: potato and firewood provision, attempts of living conditions improvement for the faculty members and students. That was a grueling time. Nonetheless, the trade union established contacts with Irbey orphan home and provided it with a material aid. The orphans were presented books (in six hundred rubles) and given five hundred fifty rubles (measured in 1950 rubles) [1].

Much efforts were made to organize amateur talent groups of students and faculty members of KPI. At the very first year of its existence the amateur talent group took part in the Inter-university Festival of Amateur Arts, regional and city Youth Festivals. There were given more than two hundred concerts that were favorably taken by the citizens of Krasnoyarsk and the region where students assisted during the harvest time. From the very beginning, the amateur talent group had a substantial material basis at its disposal. In 1957 there was a piano, four accordions, four bayans and two brass bands. There were also bought the costumes for Russian and Ukrainian dances. Regrettably, the amateur arts groups suffered the lack of human resources and it became the main drawback of the first period of its existence. That could be explained by the difficulties of the set-up period [2].

In 1965 Krasnoyarsk Polytechnic Institute was the first at the Inter-university City Festival of Amateur Arts. Nineteen participants of the KPI amateur talent group were awarded Diplomas of the Festival, among them there were 6 First place Diplomas. There were performed the following works: "The Ballade about an unknown Siberian soldier" sung by male choir, dances, and vocal pieces.

All in all, in 1965, more than a hundred of students and faculty members of KPI participated in amateur arts festivals of the Institute, supervised by art director $\mathrm{Z}$. Gurzheeva [3].

Students and academic staff of KPI took active part in political and public life of the country. They participated in the work of election committees, campaigned for the candidates, helped to maintain public order, and also issued wall newspapers. The team of agitators was created in December 1959 and numbered 68 members, half of them ( 35 people) were the students of KPI and the rest of the group was represented by the faculty members.

In 1965, the vigilant group of KPI counted 3000 members. The results of the work of the group in 19641965 year were 150 priors of juveniles to the main office where from the delinquents were taken either by parents or militia.

Many sides of the institute public life were reflected in the wall newspapers. The significant role in the reflection of the life was played by the institute newspaper "Politehnik" that was at first issued as a wallnewspaper. It had comprised 13 people by 1959 . In 1959, they issued 15 numbers and 5 numbers were published in 1960 . Headed by the chief editor V. Shub, the staff was divided into two brigades to promote the nonstop newspaper issues.

Besides "Politehnik", there were published other wall-newspapers in KPI. At the same 1959 year, there were issued 15 numbers of "Stroitel", one number of "Mashinostroitel", four issues of the paper "Za Rodinu" and etc. The foundation of satiric paper "Swezhi veter" became a real deep breath of fresh air in issuing of wall newspapers. The paper attracted attention of not only the students of KPI but the academic staff as well. It unmasked slackers, idlers, underachievers and even dishonest faculty members [4].

Radio newspaper appeared in KPI in 1961. Its Editorin-chief was V. Lavrinenko. Wholly devoting himself to the new task, soon he made the radio paper very popular among the students and faculty members [5].

The institute newspaper "Politehnik" (issued since 1964) had a great impact on forming the set of mind of future engineers.

At first, its editor-in-chief was A. Konovalov and the executive editor was L. Svintitskaya. The paper reflected all sides of institute life: scientific and academic activities, the organization of self study work, campus life, and pedagogical work. The keen criticism was laid on the existing drawbacks [6]. The new editor-in chief, T.Larskikh, was appointed in 1967 [7]. He was followed by V. Sekerina who had been holding the post for many years. She raised the level of the periodical paper to a high professional standard. Her writings included a great number of articles in regional press (mostly in "Krasnoyarsky rabochiy") created in 1970s-80s and devoted to KPI [8].

The University of culture, created in the Institute in October 1964, became a significant support in raising the cultural level of faculty members and students. There were held classes, lectures and concerts, meetings with scientists and writers (Ivan I. Sibirtsev, Anatoly I. Chmykhalo), poets (Yuri Yakhnin). The Institute was visited by masters of culture such as People's artist of Russia, a principle soloist of Bolshoi Theater Irina Maslennikova, Laureate of international contests of violinists Valery Klimov and etc. The art director of Krasnoyarsk Philharmonic A. Shvarzburg and the director of Philharmonic P. Berzak gave special lectures about music.

In April, 1965 there was held a conference of the University of Culture on "Esthetics of human behavior" where students and academic staff of KPI delivered their reports. The Rector of the University of Culture of KPI was Professor N. Kozlov [9].

The University of Culture continued its work in 1970s. It had four departments: the Department of Music, Literature department, Ethics and 
Cinematographic art department. Its contribution to the graduates' mental world formation was enormous.

The student club "Politechnik" set up similar tasks. It worked in the following areas: amateur songs club, public lecture reading, amateur arts, themed nights, International friendship club, discoclub, cinematography. Thousands of students, participating in the club activities, got necessary skills and knowledge in communication, different aspects of humanities, and patriotic education [10].

The organizational structure of the trade union activities had suffered gradual changes. In 1965, KPI changed its structure and separated the students and faculty members trade unions. Since that time they had started independent functioning. Taken as a whole, it brought its positive results enabling the trade union committee to become more goal-oriented and to serve the needs of its target group. The meetings of the trade union committee were devoted to the urgent issues of all spheres of life in KPI. The committee ran both the cultural and amateur arts, and the University of Culture.

Much attention was paid to creating the atmosphere of competitiveness between the departments, groups and hostels. The hostels of the Institute took the first places in the Competition of hostels in the framework of the Ministry of higher and secondary vocational education of the Russian Soviet Federated Socialist Republic [11]. In 1970, the hostels of KPI took part in the All-Union competition of hostels and won the second place. There were also held the inner-institute competitions of hostels. For example, hostel №3 of the Civil Engineering Faculty won the first place among the hostels of the Institute in 1970 [12].

The main goal of the competitions was to improve the students' campus life thus the major criteria in the contest assessment were living, labor and leisure conditions of the students of the Institute.

According to the report of $\mathrm{M}$. Khrebtiya, the chairman of the trade union committee in 1979, the contest for the best New Year decoration of the hostel became traditional. The trade union committee discussed and approved the regulations for review contests on "the best study laboratory", "the best curator" and "the best research and development laboratory". Every hostel had study rooms.

Nonetheless, the period of 1970s was characterized by the critical housing shortage for the faculty members. As an example, in 1977 more than 150 rooms in hostels of KPI were rented by families of the faculty members and working staff of KPI who were badly in need of housing improvements. There also lived 28 families of Candidates of Science [13].

In 1979, the trade union organization of KPI encompassed 2120 of faculty members and workers of the institute, and more than 9000 students. Part of the students lived in six hostels.

Many prize winners were rewarded financially. As an example, in 1982 twelve winners of competitions got free package holidays. At the same year, sports and health center "Ubey" took 491 people for vacation, 49 of them had family vouchers. There had been organized the third (for that period) horticulture consisting of 60 plots.
Twenty three members of the staff bought automobiles with the help of the institute [14].

In the second half of 1980, health resorts, recreation centers, holiday vacation centers, tourist and round-trip routs, and sports and health camps were at disposal for more than 300 faculty members and workers of KPI. The health center on Shira lake had being built. More than 350 people worked and rested at their garden plots [15].

The amateur arts had been developing. More than 900 people were engaged in its different activities. The institute was proud of the dance troupe, directed by A. Gulesko, the choir and the vocal group, directed by V. Podgaysky, and the light music orchestra, directed by $\mathrm{P}$. Vychulis. The faculties were also interested in amateur talent groups. The best groups were considered to be the groups of Mechanical and Electrical Engineering faculties and their art director, Z. Gurzheeva, gave of a lot of her energy and free time to develop and enhance the capability of the groups of amateur arts [16].

The number of people engaged in amateur talent groups had been increasing constantly. In the second half of 1970s there were 2000 people there. Many times the amateur talent groups of KPI won the first places at the Krasnoyarsk Inter-university Amateur Arts Festivals. For example, the amateur talent group of KPI won the first place in 1977. However, the Dean of the Electrical Engineering Faculty Prof. A. Alkin noted that the institute amateur arts seized being self-sufficient having the contests and festivals as the main goal. He pointed out that the institute needed the on-going activity of the amateur arts groups [17].

It should be mentioned that despite the difficulties stated above and the lack of accommodation, the KPI amateur talent groups survived. The Theater of Variety Miniatures was the special pride of the Institute and it kept winning the first places at regional festivals and contests for many years. In 1982, the Theater of Variety Miniatures was awarded the title of People's collective [18].

The participants of the society "Znaniye" made a great contribution to the educational work of the Institute. In 1978/1979 academic year there had been delivered 150 lectures and reports on faculties and in hostels (All in all, in Krasnoyarsk city and the Krasnoarsky Kray more than 1764). The professors of the Institute V. Ivanov, V. Koshmanov, V. Sidorenko took active part in lecturing agitation group [19].

Student construction brigade performed very well. In 1975 there were about 1640 students in the student construction brigade working in Krasnoyarsky Kray. The assimilated investments counted 4,6 mln rubles, the average output per student was 2800 (measured in 1970 rubles). The members of the student construction brigades delivered 224 lectures, performed 325 concerts, organized 5 study support centers and 4 camps-satellite. The Solidarity fund got 19,6 thousand rubles (measured in 1970 rubles), and more than 1870 people worked at harvest time on voluntary Sunday works [20].

To sum up, it is possible to notice that faculty members and students' involvement into the cultural, public and political activity contributed greatly to the training of future engineers enabling them to adapt more 
easily into the working groups after the graduation from higher educational establishments.

\section{Conclusion}

Krasnoyarsk Polytechnic Institute (KPI), founded in 1956 , became one of the leading higher educational establishments in the region. Its trade union organization influenced significantly on various spheres of life of KPI. Cultural, public, and political life of KPI in the second half of the 1950s-1980s underwent great transformation. Those transformations, characterized by emerging of various forms and approaches, were implemented into the system of cultural, public and political activities that played an important role in training and educating future specialists.

\section{Acknowledgment}

The programme was realized and subsided within the framework of the Programme for enhancing Tomsk Polytechnic University's competitiveness. The results presented herein were obtained with the assistance from Russian Fond.

\section{References}

1. Reference on the work of the trade union organization of Krasnoyarsk Polytechnic Institute. From: Documentation Center of the Modern History of Krasnoyarsk Territory (DCMH KT), Fund 6727, Inventory 1. File 4, fol. 113-114 (1956)

2. Reference on the work of the trade union organization of Krasnoyarsk Polytechnic Institute (KPI). DCMH KT, Fund 6727. Inventory 1, File 4, fol.115 (1956)

3. Report on the work of the Party Committee of KPI. From: DCMH KT, Fund 6727, Inventory 1, File 25, fol. 67 (1965)

4. Staff report of wall newspapers in KPI. From: DCMH KT, Fund 6727, Inventory 1, File 51, fol. 40 (1959)

5. Staff report of radio-newspapers in KPI. From: DCMH KT Fund, 6727, Inventory 1, File 18, fol.107 (1961)

6. Reference on the work of "Politehnik" newspaper. From: DCMH KT, Fund 6727, Inventory 1, File 25, fol. 64 (1964)

7. Staff report about the appointing of the new editorin-chief of the Institute house magazine. From: DCMH KT, Fund 6727, Inventory 1, File 87, fol. 104 (1967)

8. Report on the work of Party Committee of KPI. From: DCMH KT, Fund 6727, Inventory 1, File 87, fol.138 (1990)

9. Report on the work of University of culture of KPI. From: DCMH KT, Fund 6727, Inventory 1, File 29, fol.87 (1965)
10. Report on the work of student club "Politehnik". From: DCMH KT, Fund 6727, Inventory 1, File 27, fol.51(1966)

11. Reference on the Competition of hostels KPI. From: DCMH KT, Fund 6727, Inventory 1, File 120, fol.24 (1969)

12. Reference on the Competition of hostels KPI. From: DCMH KT, Fund 6727, Inventory 1, File 124, fol.103 (1970)

13. Report of Party Committee of KPI. From: DCMH KT, Fund 6727. Inventory 1, File 185, fol. 76 (1977)

14. Report of Party Committee of KPI. From: DCMH KT, Fund 6727, Inventory 1, File 192, fol.147 (1979)

15. Report of Party Committee of KPI. From: DCMH KT, Fund 6727, Inventory 1, File 225, fol.62 (1987)

16. Reference on the development of amateur arts in KPI. From: DCMH KT, Fund 6727, Inventory 1, File 87, fol.105 (1967)

17. Reference on the development of amateur arts in KPI. From: DCMHKT, Fund 6727, Inventory 1, File 172, fol. 69, 170 (1977)

18. Reference on the development of amateur arts in KPI. From: DCMHKT, Fund 6727, Inventory 1, File 209, fol.48 (1982)

19. Reference on the lecturing agitation group in KPI. From: DCMHKT, Fund 6727, Inventory 1, File 185, fol.50 (1979)

20. Reference on the work of student construction brigade in KPI. From: DCMHKT, Fund 6727, Inventory 1, File 124, fol.103 (1975) 